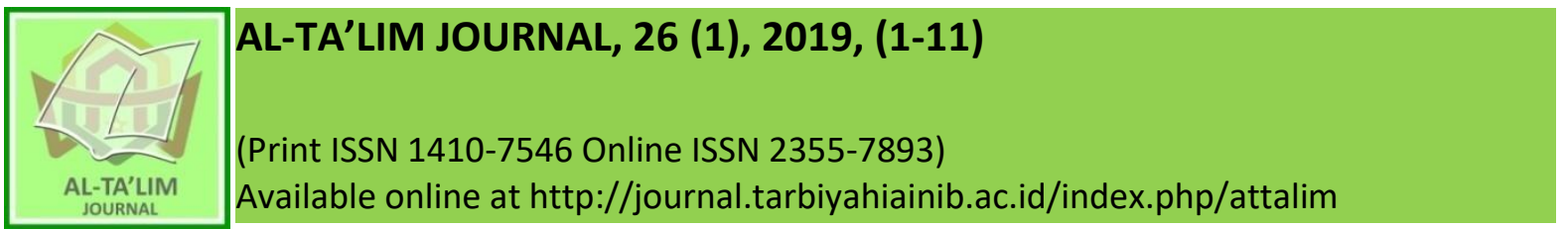

\title{
The Effect of Zikir Relaxation in Counseling to Reduce Internet Addiction
}

\author{
Received: $23^{\text {th }}$ January 2019; Revised: $04^{\text {th }}$ February 2019; Accepted: $28^{\text {th }}$ March 2019 \\ Permalink/DOI: http://dx.doi.org/10.15548/jt.v26i1.547
}

\section{Irman *)}

Institut Agama Islam Negeri

Batusangkar, Indonesia.

E-mail: irman@iainbatusangkar.ac.id

\section{Che Zarrina Saari}

University of Malaya, Malaysia

E-mail: zarrina@um.edu.my

\section{Silvianetri}

Institut Agama Islam Negeri

Batusangkar, Indonesia.

E-mail: Silvianetri.71@gmail.com

\section{Khairunnas Rajab}

Universitas Islam Negeri Sultan Syarif

Kasim Riau, Indonesia.

E-mail: khairunnasrajab@gmail.com

\section{Muhammad Zalnur}

Universitas Islam Negeri Padang,

Indonesia

E-Mail: mad_zalnur@gmail.co.id

\section{*) Corresponding Author}

\begin{abstract}
The high number of internet addiction experienced by students has been increasing for last decades. The addiction can potentially damage the brain's nerve cells, which in turn affect students' cognitive, emotion and behavior. Thus, an effective treatment is urgently needed. One of the alternatives is by employing the zikir relaxation in counseling. This study aims find the effect of zikir relaxation in counseling as the attempt to reduce the anxiety due to the internet addiction of high school students. The research method used experiment method specifically, the pretest and posttest control group design. There were 10 students taken through the random sampling. Data analysis used independent t test. The results of the study found that: (1) there was a difference level of anxiety reduction due to internet addiction for the students who received the treatment compared those who did not get, and (2) there was a significant influence between remembrance relaxations in counseling on student anxiety reduction in internet addiction. This implies that zikir relaxation is effective to use by counselors in schools to handle internet addiction.
\end{abstract}

Keywords: Remembrance relaxation; counseling; internet addiction

How to cite: Irman, I., Saari, C., Silvianetri, S., Rajab, K., \& Zalnur, M. (2019). The effect of zikir relaxation in counseling to reduce internet addiction. Al-Ta Lim Journal, 26(1). doi:http://dx.doi.org/10.15548/jt.v26i1.547

\section{INTRODUCTION}

Internet addiction can damage prefrontal cortex, then it lead the inability to make decisions and inability to solve problems as the actions do not in accordance with the applicable rules. Internet addiction appears preceded by excessive internet use.
The $2014^{\text {th }}$ Ministry of Communication and Information, states that 98 percent of Indonesian children and adolescents know the Internet, and 79.5 percent of them were actively use Internet (Beard \& Wolf, 2001; Griffiths, 2000; Nurdin \& Sibaweh, 2015; Weinstein \& Lejoyeux, 2010; Young, 2004). Some of users experience addiction, called as 
internet addiction. Azher et al. (2014) presented the research data, that there are $34 \%$ students affected by internet addiction. Hapsari \& Ariana (2015) stated that teenagers aged 10-19 years in Indonesia in 11 provinces experienced internet addiction almost $80 \%$.

The data above are worrying because internet addiction means a negative impact on life (Nalwa \& Anand, 2003; Siomos, Dafouli, Braimiotis, Mouzas, \& Angelopoulos, 2008). Muna \& Astuti, 2014; Rahmat, 2004 reveals that the internet addiction cause emotional changes. The internet addiction also causes a certain syndrome. According to Chou, Condron, \& Belland (2005) the syndrome of internet addiction make most people anxious, depressed, or empty when they cannot turn online. Thus, these opinions reinforce the internet's danger of emotional change.

The next impact of internet addiction is the disruption of social interactions. Yellowlees \& Marks (2007) revealed that people who are affected by internet addiction have problems with family, academic life and social interaction. This can be interpreted that internet addiction will affect the emotions, behavior and students' academic achievements. In a case study, at one of the State High Schools in Padang City, it was recorded that some students under the internet addiction control were very angry when their parents tried to limit the access; one of the student almost killed his parents with a knife.

Based on the results of observations and interviews with students of SMAN 12 Padang, data the use of the internet among students knows no limited time, that is, when they are at rest, when they are together with peers, even when studying. Most states that they play the internet for social media use, not for subject material. The respondent said that they use the internet approximately 6 to 8 hours a day.

Students who are exposed to internet addiction fear about decline on their academic performance as Frangos, Fragkos, \& Kiohos (2010) argues that there is a connection between internet addiction and student academic achievement, internet addiction make student academic performance decline. This means that internet addiction has a negative impact on student academic achievement. Furthermore it important to find out the way of overcoming internet addiction for students at school (Byun et al., 2009; Ha et al., 2007; Lam, Peng, Mai, \& Jing, 2009; Mitchell, 2000).

Many strategies have been proposed to prevent the internet addiction. One of them is through a counseling process conducted by the counselor. Huberty (2004) explains that individuals who experience anxiety due to internet addiction need counseling to help them. Through counseling is expected to reduce the level of anxiety caused by internet addiction. Ayunsari, Fasikhah, \& Karmiyati (2012) found that relaxation can reduce anxiety levels. Relaxation given to individuals who experience internet addiction must be relevant to the religion embraced by the client. If the client is Muslim, relaxation is used which is relaxation of zikir.

Zikir relaxation in counseling is expected to reduce the dependence on the internet. The meaning of remembrance is remembering Allah based on the values of faith in Allah. This activity make individuals who experience internet addiction relax even if they do not access the internet for a certain period of time beside reduce the level of anxiety caused by internet addition.

Perwataningrum, Prabandari, \& Sulistyarini, 2016; Soliman \& Mohamed, 2013 explains the results of his research that relaxation can reduce anxiety levels. Relaxation given to individuals who experience internet addiction must be relevant to the religion embraced by the client. If the client is Muslim, relaxation is used which is relaxation of zikir. Zikir relaxation in counseling is expected to reduce the dependence on the internet (Hatta, 2009). The meaning of zikir is remembering Allah based on the values of faith in Allah. This activity will make individuals who experience internet addiction relaxes even if they do not access the internet for a certain period of time. This 
process of relaxation of zikir will reduce the level of anxiety caused by internet addition.

\section{Internet Addiction}

Anxiety is interpreted differently by experts. Huberty (2004) defines anxiety with feelings of worry and excessive fear of reality or shadow related to cognitive, behavioral and physical. Cassady \& Johnson (2002) states that anxiety can be seen from three symptoms, namely cognitive symptoms, emotional symptoms and bodily symptoms. Cognitive symptoms are symptoms of anxiety that are detected through ways of thinking (Saraso, 2013; Zeidner, 2010). Furthermore Cassady (2001) states that cognitive characteristics of anxiety, namely: (a) fear of failure, (b) irrelevant in thinking, and (c) limitations in thinking.

Emotional symptoms are psychological symptoms in assessing a situation. These symptoms can be detected through; (a) dizzy, (b) sick and (c) panic. Bodily symptoms are physiological symptoms resulting from the emotional process response, for example wide-eyed, wheezing, facial muscles appear tense and intonation of the voice becomes elevated (Cassady \& Johnson, 2002)

Baumeister \& Vohs (2007) states that anxiety is one of the negative emotions associated with brain, respiratory and heart function. The opinions of experts above regarding anxiety, leads to a conclusion that anxiety is a negative feeling towards reality or shadow that can be viewed from three symptoms, namely cognitive, psychological and physiological which have an impact on feeling uncomfortable. One of the triggers for anxiety is internet addiction (Jost \& Liviatan, 2007; Kazdin \& Kazdin, 2000; Richard, Bond Jr, \& Stokes-Zoota, 2003).

The meaning of Internet addiction in language can be interpreted as dependence on the internet. Tao et al., (2010) explain internet addiction as a syndrome characterized by spending a very large amount of time using the internet and unable to control its use online as the effects of feeling anxious, depressed, or empty when not online on the internet (Ko, Yen, Yen, Chen, \& Chen, 2012; Song, Larose, Eastin, \& Lin, 2004).

There are several types of internet addiction. Young (2004)revealed the internet addiction subtype, namely: (1) Cybersex, (2) Addiction, (3) Cyber-Relationship Addiction, (4) Net Compulsions such as compulsive online gaming, gambling, eBay, etc (5) Information Overload, and (5) Computer Addiction-observation playing of off-line computer games. These five types of addiction have negative consequences for individuals in both psychologically and physiologically.

The opinions of various experts above are about the internet addiction provide conclusions about the notion of internet addiction, which is a feeling of anxiety, anxiety, stress and discomfort when not accessing the internet for a certain duration of time, thus it gives a negative psychological and physiological impact.

Addiction to the internet creates various negative effects for students. Romano, Osborne, Truzoli, \& Reed (2013) stated that internet addiction in the long run would lead to depression, crisis of confidence and autism. Almost at the same time, Mostafaei \& Khalili (2012) revealed that internet addiction is related to mental health, because it will cause fatigue and depression. Furthermore, Razieh, Ghasempoor, Ajdari, \& Sadeghigooghari (2012) found from his research that there was a positive correlation between internet addiction and anxiety.

Azher et al., (2014) also revealed through his research that there is a corelationship between internet addiction and anxiety, stress and depression. In line with this opinion, Akin \& Iskender (2011) also revealed that there was a positive correlation between internet addiction and depression, anxiety and stress.

The opinions of experts above suggest that internet addiction has negative impacts on individuals, as well as students. Special 
psychological effects are: feelings of anxiety, stress and depression. Then the philological impact is fatigue and insomnia. Feelings of anxiety and anxiety due to being exposed to internet addiction need to be reduced, so that students can live life effectively and efficiently. If students' anxiety is allowed to drag on, it will cause other negative effects that are more severe, namely stress and depression.

\section{Zikir Relaxation Technique in Counseling}

Interventions are suggested to use to reduce anxiety caused by internet addiction; one of those efforts is through relaxation. Sari (2009) states that relaxation techniques have been shown to be effective in reducing the level of anxiety. Kazdin (2012) states that relaxation is useful for regulating individual emotions and physically from anxiety. The meaning of relaxation is; the body's adaptive response involves "response stretching", so that the tense muscles decrease, the heart rate and blood pressure decrease and the breath works regularly (active breathing). The stimuli needed to produce decline include a quiet environment, pleasant body position and a focused mind.

Relaxation can also stimulate the emergence of chemical substances that can close the sympathetic nerve nodes and are subsequently useful to reduce tension and lower blood pressure. Davis, Eshelman, \& McKay (2008) explain that oxygen deficiency in the blood increases the likelihood of anxiety, depression and fatigue, which often makes each stressful situation more difficult to overcome. One of the activities that can increase oxygen in the blood is through relaxation.

Relaxation also increases blood flow to the brain. Jevning et al. (1996) explains through the results of his research, that during relaxation of blood flow to the kidneys and liver decreased accompanied by a significant increase in cardiac output, this supports the hypothesis that during relaxation most of the blood is distributed to the brain so that cerebral blood flow increases. This condition will make someone feel calm (Arista, 2018; Senik \& Wahab, 2013).

The most effective relaxation is if it involves the beliefs. Satyanegara (2012) revealed the results of research in Japan and Harvard Medical School found that spiritual relaxation can affect the hypothalamus, especially in the autonomic nervous system area, because the limbic system contains the hypothalamus, which controls the autonomic nervous system, decreases the limbic area and can reduce stress and increase autonomic stability by increasing the work of the hypothalamus nucleus which regulates the parasympathetic nervous system.

Relaxation combined with remembrance will give birth to maximum tranquility, as in the word of God, which means "those who believe and their hearts become content with the zikir of Allah. Remember, only by zikir of Allah is the heart secure (QS. Ar-Raddu, 28). This verse explains that zikir can bring calm and peace. The power of zikir in Islamic teachings can be used as therapy in reducing anxiety due to internet addiction.

Based on the concept of relaxation and zikir above, it can be interpreted that, relaxation of zikir is an activity that requires concentration and a quiet atmosphere and focus on zikir God by empowering thoughts and feelings to stimulate the emergence of beta-blocker chemicals on the line so as to reduce tension.

Furthermore, relaxation of zikir in the counseling process is intended as a service process in the form of training focusing on thoughts and feelings towards God to stimulate the emergence of neuronal beta blocker chemicals so that it can reduce tension with five steps, namely: (1) stretching, (2) sitting position, (3) breathing exercises (4) zikir, and (5) reflection.

In more detail, the steps of the zikir relaxation technique are as follows: The first step, stretching from head to toe. The purpose of this stretch is to make the muscles feel 
relaxed. The second step is to take a crosslegged sitting position, with a sitting bond. The palms are placed on the thighs near the knees. The left palm is placed on the left knee and right palm above the right knee. Both palms face up. Condition the body in a relaxed state, comfortable and eliminate doubts in the mind and turn to pleasant things.

It is recommend that the back in straight position. The legs were stretched and the soles of the two feet tread the earth. The right and left leg knees are stretched to form a 90 degree angle when viewed from the side. Place both palms on the right and left thighs.

The third step, concentration and inhale with 4 counts, hold your breath for 16 counts and release it slowly for 8 counts. Attempts this stages for 5 cycles, drag-breath-resistant (Lawlis \& Lawlis, 2007). Repetition of the breath-drag-and-hold cycle is also called the triangle breathing pattern commonly used in relaxation exercises. The fourth step is to pull and hold the breath, intend the whole body to start from the crown of the head to the tips of the soles of the feet to relax, relax and pass everything in the presence of the Most Merciful and Merciful. Next take the Breathe by pulling and removing breath through your nose. Stay relaxed, and zikir in the heart. Tell yourself that there is no negative power that can touch me, I am a calm person, I am a person protected by God. This relaxation position may for 15 minutes.

The last stage, namely stage five, reflects. What is meant by reflection is evaluating the effects of zikir relaxation that have been done. Assessment related to anxiety that is felt before and after doing zikir relaxation. The results of this reflection are taken into consideration in carrying out advanced zikir relaxation.

In this study zikir relaxation techniques carried out in group counseling. DeLuciaWaack (2006) explains that the stages of group activities in counseling are 3 stages: the opening stage, the activity stage and the closing stage.
Zikir relaxation techniques in group counseling are expected can bring benefits to the body, health and spiritual aspect of human. During the relaxation, the stages of zikir are repeated over and over, as well as a quiet atmosphere that can suppress the production of adrenal hormones, the trigger for anxiety as the stress relieving epinephrine hormone. Increasing epinephrine hormone increases, causing blood flow smoothly, blood pressure drops, heart burden decreases. These kinds of atmosphere ca automatically increase the immune system (Razali et al., 2017; Soliman \& Mohamed, 2013).

In light of the opinions above, it can be concluded that the stages of zikir relaxation in group counseling categorized as follows: (1) the stage of delivery, where the counselor builds psychological relationships with students. Furthermore, counselors discuss with students about the anxiety felt by internet addiction, then ask for hope regarding the problems being faced, (2) the stage of activities, contain the stages of zikir relaxation, namely 5 stages, and (3) the termination phase, which contains impressions, messages and conclusions.

The stages of zikir relaxation in counseling are the elaboration of the concept of relaxation in counseling with zikir in Islamic studies. The concept was used as an intervention in reducing anxiety due to internet addiction experienced by students. This zikir relaxation improved the students' mind peace. Retnowati (2011) explained that subjects who attended zikir relaxation training experienced a significant decrease in anxiety with a $p$ value of $0.008<(0.05)$.

Retnowati's research above meant that through the zikir relaxation it could solve the anxiety experienced by students. This research result is in line with Benson, Klipper, \& Nurhasan (2000) explains that relaxation by involving belief factor can create an internal environment that help achieve higher health and welfare conditions.

The zikir relaxation is more effective in achieving students' psychological well-being, 
especially in reducing anxiety experienced by students who are exposed to internet addiction.

\section{METHOD}

This study used experimental research, a true experiments research design, while the research design used pretest \& posttest control group design. The selection of this research design is based on the consideration that the design of this study is the right research design to test the hypothesis because it can provide adequate control so that the independent variables can be appropriately assessed (Lodico, Spaulding, \& Voegtle, 2010).

The variables are relaxation of zikir in counseling as an independent variable, and anxiety due to internet addiction as the dependent variable. The population of this study was the students of SMAN 12 Padang class students who had high levels of anxiety due to internet addiction. As for the number of samples in this study as many as 10 students were divided into two groups, namely the experimental and control groups. The instrument used in the study is the anxiety scale due to Internet addictions. Data analysis used independent $t$ test, through the help of SPPS statistics for windows version 20.00 .

\section{RESULT AND DISCUSSION}

The data in this study concerned the pretest and posttest data, both for the experimental group and for the control group. The data for the experimental group, as shown in the following table:

\begin{tabular}{|c|c|c|c|c|c|}
\hline \multirow{2}{*}{$\begin{array}{c}\text { Respon } \\
\text { dent }\end{array}$} & \multicolumn{2}{|c|}{ Pretest } & \multicolumn{2}{|c|}{ Pos-ttest } & \multirow{2}{*}{ Range } \\
\hline & Score & category & Score & Category & \\
\hline $\mathrm{A}$ & 179 & High & 89 & Low & 90 \\
\hline B & 205 & High & 87 & Low & 118 \\
\hline $\mathrm{C}$ & 175 & High & 46 & Low & 129 \\
\hline $\mathrm{D}$ & 190 & High & 49 & Low & 141 \\
\hline $\mathrm{E}$ & 204 & High & 81 & Low & 123 \\
\hline Mean & 195,6 & High & 70,4 & Low & 120,2 \\
\hline
\end{tabular}

There is a change in the level of anxiety category due to the internet addiction experienced by students, from the high category becomes low after getting the treatment. The average pretest value of 195.6 points is in the high category, while the posttest value of 70.4 points is in the low category, with a difference in the average value of 125.2 points. This means that there is a change in the level of anxiety due to overall internet addiction to students after getting zikir relaxation in counseling. Next, the control group data displayed, as shown in Table 2 below.

Table 2. Internet addiction Result of Control Group

\begin{tabular}{|c|c|c|c|c|c|}
\hline \multirow{2}{*}{$\begin{array}{c}\text { Respon } \\
\text { dent }\end{array}$} & \multicolumn{2}{|c|}{ Pretest } & \multicolumn{2}{|c|}{ Posttest } & \multirow{2}{*}{ Range } \\
\hline & score & category & Score & category & \\
\hline $\mathrm{F}$ & 178 & High & 177 & High & 1 \\
\hline G & 175 & High & 175 & High & 0 \\
\hline $\mathrm{H}$ & 179 & High & 178 & High & 1 \\
\hline I & 200 & High & 180 & High & 2 \\
\hline J & 202 & High & 170 & High & 32 \\
\hline Mean & 186,8 & High & 176 & High & 10,8 \\
\hline
\end{tabular}

The respondents in the control group were 5 students, with the treatment of usually counseling. From the research data it can be concluded that there was no change in the level of anxiety due to internet addiction, which remained in the high category. The average pretest score of 186.8 points is in the high category, while the posttest value of 176 points is in the high category, with a difference in average value of 10.8 points. This means that the control group is still experiencing anxiety problems due to internet addiction, even though there are changes but the numbers are very small.

Next, to find out the effect of zikir relaxation in counseling on decreased anxiety due to internet addictions students, independent $t$ test was performed. Before the independent $\mathrm{t}$ test, the data used had undergone prerequisite tests, namely the normality test and homogeneity test. The basic assumption is to find out the influence, decision making uses a trust level of $95 \%$ ( $\mathrm{p}=$ 0.05 ), because in the social science standard the error that can be tolerated is $5 \%$ from $100 \%$. Rejection and acceptance of each hypothesis is based on the magnitude of the pvalue or significant level (sig) of the results of 
the analysis, compared with the alpha value of $5 \%(0.05)$. If the p-value is greater than 0.05 , the null hypothesis (Ho) is accepted, and if the p-value is smaller than 0.05 then the null hypothesis is rejected. Accepted and rejected null hypothesis means contrary to the accepted and rejected hypothesis of the study. The results of the independent $t$ test data analysis, as found in Table 3 below

Tablel 3. Hasil Independent T TestInternet Addiction

\begin{tabular}{ccccc}
\hline Group & $\mathrm{N}$ & mean & Range & $\mathrm{P}$ \\
\hline control & 5 & 10,8 & & \\
Eksperiment & 5 & 120,2 & 109,4 & 0,000
\end{tabular}

Based on Table 3 above, it can be explained that the anxiety level of students who get the internet relaxation treatment is different from students who are not given the zikir relaxation intervention. Students with zikir relaxation interventions experienced a decrease in anxiety levels compared with students who did not get zikir relaxation. To test the hypothesis an independent $t$ test was conducted. The different test of the control group with the experimental group as shown in Table 3 above, shows that the value of $p=$ 0,000 . This data illustrates that the value of $p$ $<0.05$, this gives evidence of a significant difference between the control group and the experimental group.

The exposure of data about the difference test between the control group and the experimental group above proves that there are differences of the student's anxiety levels that are familiar with internet addictions after being treated compared to students who were not. The students' anxiety level was lower than students who did not get the zikir relaxation treatment. Empirically the hypotheses in the research can be accepted. There is a significant effect of zikir relaxation in counseling to decrease anxiety due to internet addiction.

This finding is in line with theory and research. Students who are exposed to the internet addiction will experience various psychological symptoms, including anxiety.
To reduce these symptoms, an intervention is needed. One of the interventions that can be done to reduce psychological symptoms due to internet addiction is relaxation of zikir. Benson (2000) reveals that meditation, relaxation, transcendental experience, has something to do with decreasing mental disorders and providing positive effects such as calmness or emotional stability. Relaxation responses that involve espoused beliefs speed up the relaxed state. In other words, the combination of relaxation responses with involving beliefs improves the benefits obtained from the relaxation response.

The zikir by repeating words rhythmically create a feeling of calm. Sangkan (2002) mentions the repetition of words or phrases rhythmically can cause the body relax. Repetition must be accompanied by a passive attitude towards stimulation both from the outside and from the inside. The lack of religious concepts can be identified by being submissive to God. This surrender attitude can multiply the relaxation response that appears.

One of the dominant psychological symptoms for students who are turn to internet addicts is feeling anxious if they don't access the internet. Zikir relaxation technique can reduce students' anxiety. Maimunah \& Retnowati (2011: 1) conclude that relaxation training with zikir can reduce anxiety significantly compared to the control group who were treated by the zikir relaxation intervention.

When students experience an internet addiction, it is difficult for them to learning seriously. Symptoms that arise are lazy to make homework, lazy to have lessons and lazy to read books. The next impact will be a decrease in learning achievement. Academic achievement is an indicator of the students' success.

The next disadvantage of students who are exposed to internet addiction is the lack of social interaction with peers, resulting in a lack of peer support. Gable, Reis, Impett, \& Asher (2004) revealed that personal sharing 
of good news to friends and how friends respond to sharing, provide social satisfaction.

Dockery (2003) states that social support provides satisfaction for individuals. Schmidt, Ambadar, Cohn, \& Reed (2006) states that the expected response in social support is an active and constructive type, meaning that communication is built in two or multiple directions and is constructive. When students are busy playing the internet, there are no two or multi-way communication. They spend time alone with the internet.

Students who have lack time to share positive things with friends tend to have low happiness. Quoidbach, Berry, Hansenne, \& Mikolajczak, 2010; Smith \& Hollinger-Smith, 2015 reveals that sharing stories about positive events with others increase happiness. Good social communication makes students happy in school.

Based on empirical data in this study it was proven that zikir relaxation techniques were effective in reducing anxiety of students affected by the internet addiction. This technique can be used by school counselors to cope students who are exposed to internet addiction. Reducing anxiety due to not accessing the internet for a certain period of time is expected to reduce addiction to the internet. This has a positive impact on student academic achievement. Later, students become more easily achieve success for their future career.

\section{CONCLUSION AND RECOMMENDATION}

Based on the results of research data analysis, it can be concluded that (1) there is different anxiety levels of students affected by internet addictions after getting the treatment of zikir relaxation with students did not get the treatment of zikir relaxation, and (2) there is a significant effect of zikir relaxation in counseling on students' anxiety control internet addiction. Based on the results of this study, it is recommended for counselors in schools to be able to use the zikir relaxation treatment in tackling the anxiety of internet addiction students.

\section{REFERENCES}

Akin, A., \& Iskender, M. (2011). Internet addiction and depression, anxiety and stress. International Online Journal of Educational Sciences, 3(1), 138-148.

Arista, D. D. (2018). Pengaruh terapi dzikir terhadap kecemasan kematian pada lanjut usia di panti sosial tresna wredha gau mabaji gowa $(\mathrm{PhD}$ Thesis). Universitas Negeri Makassar.

Ayunsari, B. R., Fasikhah, S. S., \& Karmiyati, D. (2012). Relaksasi Kesadaran Indera Untuk Menurunkan Tingkat Kecemasan Penderita Diabetes Mellitus. Jurnal Intervensi Psikologi, 4(2), 269-282.

Azher, M., Khan, R. B., Salim, M., Bilal, M., Hussain, A., \& Haseeb, M. (2014). The relationship between internet addiction and anxiety among students of University of Sargodha. International Journal of Humanities and Social Science, 4(1), 288-293.

Baumeister, R. F., \& Vohs, K. D. (2007). Encyclopedia of social psychology (Vol. 1). Sage.

Beard, K. W., \& Wolf, E. M. (2001). Modification in the proposed diagnostic criteria for Internet addiction. Cyberpsychology \& Behavior, 4(3), 377-383.

Benson, H., Klipper, M. Z., \& Nurhasan. (2000). Respons relaksasi: Teknik meditasi sederhana untuk mengatasi tekanan hidup. Kaifa.

Byun, S., Ruffini, C., Mills, J. E., Douglas, A. C., Niang, M., Stepchenkova, S., Atallah, M. (2009). Internet addiction: Metasynthesis of 1996-2006 quantitative research. CyberPsychology \& Behavior, 12(2), 203-207. 
Cassady, J. C., \& Johnson, R. E. (2002). Cognitive test anxiety and academic performance. Contemporary Educational Psychology, 27(2), 270295.

Chou, C., Condron, L., \& Belland, J. C. (2005). A review of the research on Internet addiction. Educational Psychology Review, 17(4), 363-388.

Davis, M., Eshelman, E. R., \& McKay, M. (2008). The relaxation and stress reduction workbook. New Harbinger Publications.

DeLucia-Waack, J. L. (2006). Leading psychoeducational groups for children and adolescents. Sage Publications.

Dockery, A. M. (2003). Happiness, life satisfaction and the role of work: Evidence from two Australian surveys. Full Employment Imperative, The, 77.

Frangos, C. C., Fragkos, K. C., \& Kiohos, A. (2010). Internet addiction among Greek university students: Demographic associations with the phenomenon, using the Greek version of Young's Internet Addiction Test. International Journal of Economic Sciences and Applied Research, 3(1), 49-74.

Gable, S. L., Reis, H. T., Impett, E. A., \& Asher, E. R. (2004). What do you do when things go right? The intrapersonal and interpersonal benefits of sharing positive events. Journal of Personality and Social Psychology, 87(2), 228.

Griffiths, M. (2000). Does Internet and computer" addiction" exist? Some case study evidence. CyberPsychology and Behavior, 3(2), 211-218.

Ha, J. H., Kim, S. Y., Bae, S. C., Bae, S., Kim, H., Sim, M., ... Cho, S. C. (2007). Depression and Internet addiction in adolescents. Psychopathology, 40(6), 424-430.

Hapsari, A., \& Ariana, A. D. (2015). Hubungan antara Kesepian dan Kecenderungan Kecanduan Internet pada Remaja. Jurnal Klinis Dan Kesehatan Mental, 164-171.

Hatta, Z. A. (2009). Exploring Traditional Approaches for the Helping Profession: The Sufi Model. Tawarikh, 1(1).

Huberty, T. J. (2004). Anxiety and anxiety disorders in children: Information for parents. National Association of School Psychologists, 1-6.

Jost, J. T., \& Liviatan, J. (2007). Encyclopedia of social psychology.

Kazdin, A. E. (2012). Behavior modification in applied settings. Waveland Press.

Kazdin, A. E., \& Kazdin, A. E. (2000). Encyclopedia of psychology (Vol. 2). American Psychological Association Washington, DC.

Ko, C.-H., Yen, J.-Y., Yen, C.-F., Chen, C.S., \& Chen, C.-C. (2012). The association between Internet addiction and psychiatric disorder: A review of the literature. European Psychiatry, 27(1), 1-8.

Lam, L. T., Peng, Z., Mai, J., \& Jing, J. (2009). Factors associated with Internet addiction among adolescents. Cyberpsychology \& Behavior, 12(5), 551-555.

Lawlis, F., \& Lawlis, G. F. (2007). The IQ answer: Maximizing your child's potential. Penguin.

Lodico, M. G., Spaulding, D. T., \& Voegtle, K. H. (2010). Methods in educational research: From theory to practice (Vol. 28). John Wiley \& Sons. 
Mitchell, P. (2000). Internet addiction: Genuine diagnosis or not? The Lancet, 355(9204), 632.

Mostafaei, A., \& Khalili, M. (2012). The relationship between Internet addiction and mental health in male and female university students. Annals Biol Res, 3(9), 4362-6.

Muna, R. F., \& Astuti, T. P. (2014). Hubungan antara kontrol diri dengan kecenderungan kecanduan media sosial pada remaja akhir. Empati, 3(4), 481-491.

Nalwa, K., \& Anand, A. P. (2003). Internet addiction in students: A cause of concern. Cyberpsychology \& Behavior, 6(6), 653-656.

Nurdin, D., \& Sibaweh, I. (2015). Pengelolaan Pendidikan Dari Teori Menuju Implementasi. Jakarta: Raja Grafindo Persada.

Perwataningrum, C. Y., Prabandari, Y. S., \& Sulistyarini, R. I. (2016). Pengaruh Terapi Relaksasi Zikir Terhadap Penurunan Tingkat Kecemasan Pada Penderita Dispepsia. Jurnal Intervensi Psikologi, 8(2).

Quoidbach, J., Berry, E. V., Hansenne, M., \& Mikolajczak, M. (2010). Positive emotion regulation and well-being: Comparing the impact of eight savoring and dampening strategies. Personality and Individual Differences, 49(5), 368-373.

Rahmat, H. S. W. S. R. (2004). Kontrol diri dan kecenderungan kecanduan internet. Humanitas: Jurnal Psikologi Indonesia, 1(1).

Razali, H., Husain, R., Rahim, M., Endut, N. N., Mat, K. C., Simbak, N., \& Latif, A. Z. A. (2017). Impacts Of Three Different Relaxation Techniques On Mood States Among Athletes. Malaysian Journal of Public Health Medicine, (2), 49-58.
Razieh, J., Ghasempoor, A., Ajdari, Z., \& Sadeghigooghari, N. (2012). The relationship between Internet addiction and anxiety in the universities students. Interdisciplinary Journal of Contemporary Research in Business, 4(1), 942-949.

Retnowati, S. (2011). Pengaruh pelatihan relaksasi dengan dzikir untuk mengatasi kecemasan ibu hamil pertama. Psikoislamika: Jurnal Psikologi Dan Psikologi Islam, 8(1).

Richard, F. D., Bond Jr, C. F., \& StokesZoota, J. J. (2003). One hundred years of social psychology quantitatively described. Review of General Psychology, 7(4), 331-363.

Romano, M., Osborne, L. A., Truzoli, R., \& Reed, P. (2013). Differential psychological impact of internet exposure on internet addicts. PLoS One, 8(2), e55162.

Sangkan, A. (2002). Berguru Kepada Allah. Bukit Thursina: Jakarta.

Saraso11, I. C. (2013). Test anxiety, worry, and cognitive interference. In Selfrelated cognitions in anxiety and motivation (pp. 29-44). Psychology Press.

Sari, A. D. K. (2009). Pelatihan teknik relaksasi untuk menurunkan kecemasan pada primary caregiver penderita kanker payudara. Gadjah Mada Journal of Professional Psychology (GamaJPP), 1(3).

Schmidt, K. L., Ambadar, Z., Cohn, J. F., \& Reed, L. I. (2006). Movement differences between deliberate and spontaneous facial expressions: Zygomaticus major action in smiling. Journal of Nonverbal Behavior, 30(1), $37-52$.

Senik, M. R., \& Wahab, M. N. A. (2013). A pilot study of the effect of zikir on the performance psychology using heart 
rate variability (hrv). 4th International Graduate Conference on Engineering, Science \& Huminities (IGCESH), 1617.

Siomos, K. E., Dafouli, E. D., Braimiotis, D. A., Mouzas, O. D., \& Angelopoulos, N. V. (2008). Internet addiction among Greek adolescent students. CyberPsychology \& Behavior, 11(6), 653-657.

Smith, J. L., \& Hollinger-Smith, L. (2015). Savoring, resilience, and psychological well-being in older adults. Aging \& Mental Health, 19(3), 192-200.

Soliman, H., \& Mohamed, S. (2013). Effects of zikr meditation and jaw relaxation on postoperative pain, anxiety and physiologic response of patients undergoing abdominal surgery. Journal of Biology, Agriculture and Healthcare, 3(2), 23-38.

Song, I., Larose, R., Eastin, M. S., \& Lin, C. A. (2004). Internet gratifications and
Internet addiction: On the uses and abuses of new media. Cyberpsychology \& Behavior, 7(4), 384-394.

Tao, R., Huang, X., Wang, J., Zhang, H., Zhang, Y., \& Li, M. (2010). Proposed diagnostic criteria for internet addiction. Addiction, 105(3), 556-564.

Weinstein, A., \& Lejoyeux, M. (2010). Internet addiction or excessive internet use. The American Journal of Drug and Alcohol Abuse, 36(5), 277-283.

Yellowlees, P. M., \& Marks, S. (2007). Problematic Internet use or Internet addiction? Computers in Human Behavior, 23(3), 1447-1453.

Young, K. S. (2004). Internet addiction: A new clinical phenomenon and its consequences. American Behavioral Scientist, 48(4), 402-415.

Zeidner, M. (2010). Test anxiety. The Corsini Encyclopedia of Psychology, 1-3. 